\title{
The Role of XBRL in Europe
}

\author{
Enrique Bonsón. Universidad de Huelva. Spain. \\ bonson@uhu.es
}

\begin{abstract}
Digital financial statements have been designed under two main hypotheses: The first one considers that human beings are their target audience and the second one assumes that users belong to a specific accounting jurisdiction or capital market. Obviously, these hypotheses are no longer accepted. The former because it is necessary to make machines understand the accounting language to facilitate the automatic exchange of information between softbots and/ or software applications. The latter because in order to facilitate securities markets globalization it is necessary to adopt a unique set of international accounting standards. These two needs have to be satisfied. The response to the first one is XBRL, the Extensible Business Reporting Language. The European solution to the second one, is going to be the adoption of the IASB's International Accounting Standards. In this paper, the role of XBRL in the European solution is analyzed. The main conclusions are that the adoption of IAS and the use of XBRL will facilitate the communication of information in a homogeneous way, that they will allow the interchange of data between software applications and also the automatic analysis of financial information. In summary, they are going to play a key role for the development of the global European Stock Market.
\end{abstract}

Keywords: Digital reporting, XBRL, International accounting standards

Acknowledgements. The present paper was made possible by financial support from the Spanish Ministry of Science and Technology. Research project BEC2001-3356. Thanks are given to Virginie Lepers for her assistance in English translation and to the two anonymous reviewers for their insightful comments on an earlier draft of this manuscript. 


\section{INTRODUCTION}

The dissemination of accounting information by means of Internet adds a new dimension to corporate reporting. Online, real time, information will soon replace historical financial statements at present being provided by companies to stakeholders. Businesses could provide current information used by managers for decision making. Search and presentation capabilities of the Internet will allow companies to add value to their corporate information. Companies should be able to offer to main stakeholders a wide range of additional non financial information that could be accessed on demand depending on the stakeholders' interests.

The main accounting organizations (ICAEW, 1997 and 1998, IASC, 1999, CICA, 1999 and FASB, 2000), have sponsored some studies aiming to analyze the implications for the accounting profession. They have highlighted the need to establish a set of standards which would allow the companies to structure the information provided.

The situation in Europe has been widely studied in the accounting literature (Bonsón, 2000, Bonsón et al., 2000, Brennan and Hourigan, 1998, Craven and Marston, 1999, Craven and Otsmani, 1999, Deller et al., 1998, Gowthorpe and Amat, 1999, Heldin, 1999, Lymer, 1999, Lymer and Tallberg, 1997 and Pirchergger et al. 1999). Findings confirm that there is an increasing number of companies adopting the Web for the electronic dissemination of accounting information. Corporations are using the Internet to make voluntary financial disclosures as a mean to satisfy information demands from shareholders and other corporate stakeholders. Practices include not just providing traditional annual report but supplying more information by: improving timeliness (half year and quarterly reports), making environmental information available, providing investor services such as sending e-mails of company announcements and press releases, information about employment and job opportunities, etc.

In a survey on Eurotop 100 listed companies (see Bonsón, 2000), it was found that $100 \%$ of the companies had active Web sites and that $99 \%$ supplied the full annual accounts. Interim statements (half year or quarterly) were commonly found (64\%), but they were not audited. A number of companies (47\%) provided five years summary accounts and a few of them (24\%) included financial ratios. Five companies were found, all of them from Germany, reporting under IASB's International Accounting Standards. Companies listed in the New York Stock Exchange also provided either the full accounts under USA GAAP or a link to the 
forms filed electronically in the EDGAR Database to fulfill SEC requirements. Environmental information was disclosed by 34 companies. More than a half (54\%) provided information on strategy. Almost all of the sites (94\%) made press releases available and 28 companies offered mailing lists to keep stakeholders currently informed by e-mail. Shareholders' information included: news (83\%), meetings (34\%) and structure (31\%). No real time information was found except for share prices.

The publication on the Web of digital financial statements is, certainly, a practice that has already reached its maturity. The mechanisms that have been used range from digital reproduction of printed documents (.pdf files) to downloadable financial statements in spreadsheet format, passing through the publication of hypertexts (.html files). All of these mechanisms have in common that they have been designed thinking in a unique type of users: the human beings.

Internet users are facing an information overload phenomenon. It leads to the need of using new software applications (software agents or softbots). These applications, based on a principal-agent relationship, are able to perform certain tasks in behalf of their users (search, retrieval, structure and analysis). None of the distribution systems cited below permits the efficient usage of these new applications because they do not provide a consistent way for applications to extract data.

Digital financial statements have been designed under two main hypotheses: The first one considers that human beings are their target audience and the second one assumes that users belong to a specific accounting jurisdiction or capital market. Obviously, these hypotheses are no longer accepted. The former because it is necessary to make machines understand the accounting language to facilitate the automatic exchange of information between softbots and/or software applications. The latter because in order to facilitate securities markets globalization it is necessary to adopt a unique set of international accounting standards. These two needs have to be satisfied. The response to the first one is XBRL, Extensible Business Reporting Language. The European solution to the second one, is going to be the adoption of the IASB's International Accounting Standards.

\section{THE EUROPEAN UNION FINANCIAL REPORTING STRATEGY}

Currently there are many different financial reporting rules and different interpretations based on different traditions within the European Union that present 
inconsistencies, many of them of major importance. To remove these accounting differences as a step forward towards a global securities market, the European Commission has outlined on June 2000 a strategy for future financial reporting in Europe. The strategy has been designed to eliminate remaining barriers to crossborder trading in securities, in particular by recommending the adoption of one set of accounting standards so that company accounts throughout the European Union can be more easily compared. It will make it easier for European companies to comply with the financial reporting requirements of international capital markets and thus, compete on equal terms with non-European companies.

In February 2001, the European Commission presented a proposal for a Regulation that would require all European Union companies listed on a regulated market, including banks and insurance companies, to prepare consolidated accounts in accordance with International Accounting Standards ${ }^{1}$ (IAS). This requirement would enter into force at the latest in 2005. Member States would have the option to extend this requirement to unlisted companies and to the production of individual accounts.

The Regulation will directly concern around 6700 listed European Union companies, which will have to prepare their consolidated accounts in accordance with International Accounting Standards by 2005. At the moment, only 275 listed European Union companies are using these standards for their financial reporting and only seven Member States (Austria, Belgium, Germany, France, Finland, Italy, and Luxembourg) specifically allow listed companies to prepare their consolidated financial statements in accordance with them.

The Commission has already carried out an examination of the conformity of the existing IAS and Interpretations of the Standing Interpretations Committee (SIC) with the Accounting Directives - namely the 4th Company Law Directive (78/660/EEC) and the 7th Directive on consolidated accounts (83/349/EEC). Discrepancies (very few) have been addressed in the context of a Directive to modernise European Union accounting rules adopted on 31 May 2001 by the European Union's Council of Ministers and the European Parliament. The Directive

\footnotetext{
1 IAS are investor-oriented accounting standards developed by the IASC, the International Accounting Standards Committee, set up in the seventies by the accountancy bodies of a number of industrialised countries. In May 2000, the International Federation of Accountants (IFAC) approved a new structure for IASC and since April 2001 it is called IASB (International Accounting Standards Board).
} 
introduces the "fair value" accounting method and amends the Accounting Directives to take into account the developments in markets, business and international accounting standards. The main objective of the Directive is to enable companies to fully apply International Accounting Standards (IAS) within the framework of the Accounting Directives.

An accounting technical committee, named "European Financial Reporting Advisory Group" (EFRAG), has been set up by the main actors interested in financial reporting (including users, preparers, the accounting profession and national standard setters). The committee would provide technical expertise concerning the use of International Accounting Standards within the European legal environment. It would participate actively in the international accounting standard setting process and organise the coordination of views concerning international accounting standards within the European Union.

The changeover from national accounting rules to International Accounting Standards will entail a substantial amount of training both for the accounting profession and for the companies which will have to comply for the first time with IAS. It will also mean some costs but the long term return on this investment will be substantial. The increased transparency and the improved comparability of financial information will ultimately result in a reduction of the cost for companies of raising capital. This will help to enhance the competitiveness of European industry. In addition, the adoption of International Accounting Standards as the European standard for financial reporting will increase the legitimacy of these standards world-wide.

\section{XBRL. THE IASB TAXONOMY}

The development of the Extensible Business Reporting Language (XBRL) aims to facilitate the automatic exchange of information between software applications $\mathrm{XBRL}^{2}$ uses a set of taxonomies to provide a specific framework for data interchange according to existing reporting standards. A taxonomy is an XML Schema that defines new elements each corresponding to a concept that can be referenced in XBRL documents. XBRL taxonomies can be considered as extensions of XML Schema In

\footnotetext{
2 For further details on XBRL see Coffin (2001), Debreceny and Gray (2001), Hoffman et al. (2001) and Strand et al. (2001).
} 
addition to the US-GAAP-C\&I taxonomy, there is a number of taxonomies being developed for different accounting jurisdictions and industries.

For companies reporting under International Accounting Standards, the International Accounting Standards Board is developing a taxonomy: The IASC\&I taxonomy. The first draft of the IAS-C\&I taxonomy was presented at the first XBRL International meeting in London, February 2001. The taxonomy has been updated to beta-3. This version is different from previous IAS beta releases because it has been aligned with the ongoing efforts of the XBRL specifications group. Beta-3, which is close to the final IAS release, was presented at the second International XBRL meeting in New Orleans, June 2001. The approach of beta-3 version is based upon the IAS dictionary of XBRL terms and follows an objectoriented design. The taxonomy, which is based on International Accounting Standards, will help many countries to develop and implement XBRL for financial statements.

To obtain a better understanding of the taxonomy, a list of the element names used to identify each data item in the IAS Income Statement is provided in table 1. Element labels according to the International Accounting Standard number 1 (IAS1) paragraph 75, are also provided in English and Spanish languages.

\begin{tabular}{|l|l|l|l|}
\hline IAS Ref. & Element name & English label & Spanish label \\
\hline 1.75.a & inc_exp-ord-ops-rev-gross & Revenues & Ingresos \\
\hline $1.75 . \mathrm{b}$ & inc_exp-ord-ops-net & Results from operating activities & Resultados de las operaciones \\
\hline $1.75 . \mathrm{c}$ & inc_exp-ord-finCost-net & Finance costs & Gastos financieros \\
\hline $1.75 . \mathrm{d}$ & $\begin{array}{l}\text { inc_exp-ord-jv } \\
\text { inc_exp-ord-assoc }\end{array}$ & $\begin{array}{l}\text { Share of profits and losses of } \\
\text { associates and joint ventures } \\
\text { for using the equity method }\end{array}$ & $\begin{array}{l}\text { Participación en las pérdidas } \\
\text { y ganancias de las empresas } \\
\text { asociadas y coparticipadas } \\
\text { llevadas por el método de } \\
\text { puesta en equivalencia }\end{array}$ \\
\hline 1.75.e & inc_exp-ord-tax & Tax expense & $\begin{array}{l}\text { Gasto por el impuesto sobre } \\
\text { beneficios }\end{array}$ \\
\hline 1.75.g & inc_exp-extord-net & Extraordinary items & Resultados extraordinarios \\
\hline $1.75 . \mathrm{h}$ & inc_exp-ord-minInt & Minority interests & Intereses minoritarios \\
\hline $1.75 . \mathrm{i}$ & inc_exp-net & Net profit or loss for the period & $\begin{array}{l}\text { Beneficio neto o pérdida del } \\
\text { ejercicio }\end{array}$ \\
\hline
\end{tabular}

Table 1. Element names with their corresponding labels in English and Spanish languages for financial items in the IAS Income Statement (provisional version)

Although one of the key internationalisation features of XBRL is that element labels have the possibility to be declared in different languages, recasting the underlying financials under a different set of national accounting principles is a far more complex matter. In any taxonomy, a given set of financial statements could be presented by a single application in a language selected by the user but 
the presentation under different accounting standards is not so easy. The great advantage of the IAS taxonomy is that all the countries reporting under IAS use the same set of standards, that is the International Accounting Standards. It makes it easier to present highly understandable financial statements into the users' language. The taxonomy will include a unique set of element names and different sets of element labels using different languages.

Furthermore, the IAS taxonomy will provide the possibility to use the alternative accounting valuation methods allowed by the International Accounting Standards. For example, there will be a set of different labels for fixed assets valued under historical cost or fair value. By this way, any software agent will be able to recognise the valuation method and indicate it to the user.

A jurisdictional taxonomy ensures the automatic data exchange between applications that use the taxonomy as a reference. As new taxonomies are coming out in the international reporting arena, a new kind of applications aiming to facilitate the conversion among financial statements will be born (see Coffin, 2001). It will only be a matter of defining the differences between two taxonomies and specifying, in the source document, the information not required by the source taxonomy but needed by the target one to make the conversion of the document possible. For example, a company reporting under IAS, but using historical cost valuation methods, should include, in its XBRL instance documents, information on the same items under fair value, in order to facilitate alternative disclosure. In countries in which national accounting standards are (or will be) similar to IAS the approach to develop jurisdictional taxonomies would be that of using the IAS taxonomy as a base. This could be done by extending the IAS taxonomy or by cutting and pasting it to a separate national taxonomy.

\section{CONCLUSIONS}

As noted by Mike Willis (2000), chair of the XBRL Steering Committee, in a digital world, reporting should be considered as an information supply chain. A report publication is no longer the end of the chain but a real input for others. In this sense, XBRL, that is an XML specific application for financial information supply chain, will benefit all participants, from companies to data aggregators and mainly to the final users. In Europe, those benefits will be higher because the adoption of IAS will provide a unique framework for financial reporting and it will enhance the applicability of XBRL. In particular the benefits will be: 
- For companies preparing their financial statements under the IAS taxonomy because it will only be necessary to prepare them once in XBRL. This will automatically allow the publication in different ways (printed report, corporate Web site, electronic submission to securities commissions, tax authorities, banks, etc.) and the translation to all the European Union languages ${ }^{3}$. In addition, XBRL will enhance the transition to IAS for those companies currently using their local standards.

- For financial analysts, investors and regulators because XBRL is going to increase the possibilities to use the financial statements information and to automatically analyse it. It will also significantly reduce the need to re-key financial data from a format to another one. And it will allow to receive information in the user's favourite format and language.

- For data aggregators and financial information providers because automatic data capture will imply a reduction of both preparation costs and re-keying errors. It will also make possible a deeper concentration on adding value to data.

- For software vendors because the possibility to import and export files in XBRL format will increase their connectivity with other applications.

Financial information availability will determine whether a company is going to be appreciated or ignored by the capital markets, that's why high performance financial reports will be a must. In Europe, the adoption of IAS and the use of XBRL, will satisfy the market's demands. They will allow the communication of information in an homogeneous way, the interchange of data between software applications and the automatic analysis of financial information. In summary, they are going to play a key role for the development of the global European Stock Market.

\section{REFERENCES}

Bonsón, E. (2000): "Digital Reporting Practices in Europe. A Survey on Eurotop 100 Companies", Paper presented at the ninth Workshop on Artificial Intelligence and Emerging Technologies in Accounting. 12 August 2000, Philadelphia, USA.

Bonsón, E., Escobar, T. and Sánchez, M. (2000): "Corporate Digital Reporting in Europe. A Survey on Eurostoxx50 Companies", Paper presented at the 3rd European Conference in Accounting Information Systems, Munich, Germany.

\footnotetext{
3 Note that most of the reports will be in the Euro currency and under IAS, what makes European investors' understandability close to perfection.
} 
Brennan, N. and Hourigan, D. (1998): "Corporate Reporting on the Internet by Irish Companies", Accountancy Ireland; December, pp.18-21.

Coffin, Z. (2001): “The Top Ten Effects of XBRL”, Strategic Finance, June, pp. 64-67.

Craven, B.M. and Marston, C.L. (1999): "Financial Reporting on the Internet by Leading UK Companies", European Accounting Review, vol. 8, n. 2.

Craven, B. M. and Otsmani, B. (1999): "Social and Environmental Reporting on the Internet by Leading UK Companies", Paper presented at the 22nd Annual Congress of the European Accounting Association, Bordeaux, France.

Debreceny, R., and Gray, G. (2001): "The Production and Use of Semantically Rich Accounting Reports on the Internet: XML and XBRL", International Journal of Accounting Information Systems, n. 2. pp-47-74.

Deller, D., Stubenrath, M. and Weber, C. (1998): "Investor Relations and the Internet. Background, Potential Application and Evidence from the USA, UK and Germany", Paper presented at the 21st Annual Congress of the European Accounting Association, Antwerp, Belgium.

FASB (2000): Electronic Distribution of Business Reporting Information. Steering Committee Report Series. http://www.fasb.org

Gowthorpe, C. and Amat, O. (1999): "External Reporting of Accounting and Financial Information via the Internet in Spain", European Accounting Review, vol. 8, n. 2.

Heldin, P. (1999): "The Internet as a Vehicle for Investor Information; the Swedish Case", European Accounting Review, vol. 8, n. 2.

Hoffman, C., Strand, C. and Coffin, Z. (2001): XBRL Essentials, KPMG, Seattle Pacific University \& XBRL Solutions.

ICAEW (1998): The 21 $1^{\text {st }}$ Century Annual Report, (ICAEW), London.

Lymer, A. (1999): "The Internet and the Future of Corporate Reporting in Europe", European Accounting Review, vol. 8, n. 2.

Lymer, A., Debreceny, R., Gray, G. and Rahman, A. (1999): Business Reporting on the Internet. A Report Prepared for the International Accounting Standards Committee. IASC. London. 
Lymer, A. and Tallberg, A. (1997): "Corporate Reporting and the Internet - a Survey and Commentary on the Use of the WWW in Corporate Reporting in the UK and Finland". Paper presented at the 20th Annual Congress of the European Accounting Association, Graz, Austria.

Pirchegger, B., Schader, H. and Wagenhofer, A. (1999): "Financial Information on the Internet. A Survey of the Homepages of Austrian Companies", European Accounting Review, vol 8, n. 2.

Spaul, B. (1997): Corporate Dialogue in the Digital Age, The Institute of Chartered Accountants in England and Wales (ICAEW), London.

Strand, C., McGuire, B., Watson, L. and Hoffman, C. (2001): "The XBRL Potential" Strategic Finance, June, pp. 58-63.

Trites, G.D. (1999): The Impact of Technology on Financial and Business Reporting, Canadian Institute of Chartered Accountants, CICA, Toronto, Canada.

Willis, M. (2000): Corporate Communications for the $21^{\text {st }}$ Century. How E-business is Redefining the Business Information Supply Chain. PriceWaterhouse Coopers. 